\title{
Impact of Procedure Manual in a Cleaning Company
}

\section{Kenia Valeria Gamboa Hernández ${ }^{1}$, Patricia Lyssett Bellato Gil ${ }^{3}$, Verónica Flores Sánchez ${ }^{3}$, Daniel Martínez Navarrete ${ }^{4}$}

\author{
${ }^{1}$ Department of HR, High Tech Services, México \\ Email: keniagamboa92@gmail.com \\ ${ }^{2}$ Department of DNM, Universidad Tecnológica del Centro de Veracruz, Veracurz, México \\ Email: lyssett.bellato@utcv.edu.mx \\ ${ }^{3}$ Department of IMI, Universidad Tecnológica del Centro de Veracruz, Veracurz, México \\ Email: calidad.utcv@gmail.com \\ ${ }^{4}$ Department of DNM, Universidad Tecnológica del Centro de Veracruz, Veracurz, México \\ Email: daniel.martinez@utcv.edu.mx
}

\begin{abstract}
This project is developed in a cleaning company, which we will call "Clean Express" to maintain the anonymity of the same, said company is located Boca del Rio, Veracruz, Mexico.

According to Gido in 2012, the case study company has a functional type structure because the departments group the areas.
\end{abstract}

Keywords-Cleaning, franchising, certification.

\section{INTRODUCTION}

The largest franchise in the world that specializes in cleaning carpets and furniture has more than 4,000 franchises in 43 countries.

In Mexico, 62 franchises operate in 30 cities, more than 100 million square meters of carpets are cleaned every year by more than 16,000 specialized technicians from around the world in apartments, residences, offices, hotels, restaurants, shops and any type of property with carpeted areas.

The excellent results obtained in carpet cleaning have generated demand on cleaning mats, furniture, screens, mattresses, car interiors and other items, providing great satisfaction to customers.

The cleaning company that is the focus of this project, arrived in Mexico because two entrepreneurs were looking for a commercial opportunity to become independent.

After analyzing the different business options, identify that the cleaning franchise that occupied the first places prestigious magazines such as US Entrepreneur.

Another important factor in the decision is the investment that is required to start the business, without neglecting the great advantages and benefits of the carbon dioxidebased cleaning system.
It is worth noting that excellent comments from managers of similar franchise services in other countries and the great need for this service in Mexico led to the creation of "Clean Express" in Mexico in 1992.

Clean Express, Veracruz opens its doors in 1995 to the service of the residential, commercial, automotive and hotel sector.

Derived from growth and seeking to exceed the expectation of service in 1998, it acquires an important cleaning franchise that is recognized worldwide for the products that support it.

Clean Express currently has an SOA seal (Seal Of Approval), awarded by the Carpet and Rugs Institute (CRI "Carpet and RugInstitute").

The preparation of a manual of procedures will help to systematize and standardize the activities of the different processes in charge of each employee as required by the positions within the company.

The manual will help to contribute to the fulfillment of the objective, or of the substantive purposes of the Institution, in an efficient manner and allowing an optimum use of the resources.

Understanding that a procedure is a document in which the different activities necessary to complete a task are compiled or grouped, with the purpose of establishing an adequate communication to the involved actors that allows them to carry out their tasks in an orderly and systematic way (Ponce, 2013).

A. Reyes Ponce in 2013 describes the procedures as brochures, books, folders, etc., in which an easy way to concentrate systematically, a series of administrative elements for a specific purpose. This allows guiding and standardizing the behavior that occurs between each human group in the company. 
This is how Graham Kellog indicates that a written procedure means properly establishing a standard method to perform some work (Ponce, 2013).

It is clear then, that the Procedural Manual gives a formal or official character to the procedures for a specific task or set of tasks, becoming a guiding guide in the achievement of an effective and efficient result (Ponce, 2013).

Therefore, the preparation of Procedural Manuals within the institution or company is a function of the directors, managers and other people with decision-making authority, leading to keep employees well informed on how to perform tasks of their competence and thus avoid confusion when carrying out their functions, but they serve, at the same time, as an instrument of accountability about what, how, when and where the tasks that are the responsibility of each official (Ponce, 2013).

\section{RESEARCH PROPOSAL}

The preparation of the manual aims to:

1. Make all involved personnel aware of institutional responsibilities and policies.

2. Promote the uniformity of work, allowing different collaborators to perform different tasks without any inconvenience.

3. Avoid duplication of functions.

4. Increase adminis trative efficiency.

5. Facilitate the induction of new collaborators.

6. Save efforts and resources.

In the first stage of the project you must determine the activities that must be carried out within the company, to achieve the objectives for which it was created.

In the second stage the organizational structure is defined. The third stage consists of validating the activities carried out by the personnel of each area, the former to justify each position within the organizational structure.

Finally, the productivity and effectiveness of the employee must be evaluated every six months according to each position.

For the collection of information, techniques such as:

1) Participatory observation in which the investigator became an observer of the process (Taylor, 1984). During this practice it was possible to understand the sequence of tasks in the processes.

2) The exploratory interview, where each of the workers of the company was interviewed in order to know the working methods used.

To process the data it is necessary to use descriptive statistics, but above all the analysis of the existing methodologies.
An important part of this research is writing the work procedures in each of the areas that make up the company.

It is worth noting that the cleaning and disinfection programs must guarantee the proper hygiene of the entire establishment, as well as the equipment used for cleaning and disinfection.

The foregoing implies the supervision of a continuous and effective way to verify its adequacy and efficiency.

\section{CONCLUSION}

The implementation of procedures manuals in cleaning companies arises from the problem of non-compliance with goals and waiting times for customers.

The implementation of the manuals allows knowing the specific activities of each department, in this way the tasks; the time and forms of these are observed.

Each area has quality codes in order to achieve the fulfillment of goals and objectives, however the manual allows standardizing them and making them universal for the company.

It is important to mention that the procedure manual was made for 9 departments that make up the entire company. In the billing and collection department, the activities and the fulfillment of the goals were improved by $50 \%$, in the same way $70 \%$ of the accounts receivable were recovered.

The manuals of procedures are of great help to standardize processes, thus allowing reaching the goals established by the organization.

\section{REFERENCES}

[1] Breth, R. (1974). Las comunicaciones en la dirección de empresas. España: Fondo Educativo Interamericano.

[2] Dessler, G. (2015). Administración de Recursos Humanos. México: Pearson.

[3] Gibson, J., Donnelly, J., \& Konopaske, R. (2011). Organizaciones. Comportamiento, estructura $\mathrm{y}$ procesos (13 ${ }^{\mathrm{a}}$ ed.). México: McGraw Hill.

[4] Gido, J., \& Clements, J. (2012). Administración exitosa de proyectos ( $5^{\text {a }}$ ed.). México: Cengage Learning.

[5] González, M. (26 de Diciembre de 2006). La rotación de personal como un elemento laboral. Recuperado el Marzo de 2017, de Universidad Autónoma de Nuevo León: http://eprints.uanl.mx/1718/1/1020154556.PDF

[6] Hellriegel, D., Jackson, S., \& Slocum, J. (2002). Administración. Un enfoque basado en competencias. México: S.A. Ediciones Paraninfo. 
[7] Koontz, H., Weihrich, H., \& Cannice, M. (2012). Administración. Una perspectiva global y empresarial. (14 ed.). México: McGraw Hill.

[8] Millán, G. (26 de Marzo de 2006). Rotación de Personal. Recuperado el 2017, de Universidad Autónoma Metropolitana: http://148.206.53.84/tesiuami/UAMI13478.pdf

[9] Ponce, R. (2013). RIS Solutions. Obtenido de http://ris solutions.com/importancia-de-losmanuales-de-procedimientos-en-la-gestionadministrativa/

[10] Project Management Institute, Inc. (2013). Guía de los fundamentos para la dirección de proyectos (Guía del PMBOK) (5 $5^{\mathrm{a}}$ ed.). Estados Unidos: PMI Publications.

[11] Stephen, R., \& Coulter, M. (2013). Administración. México: Pearson.

[12] Werther, W., \& Davis, K. (2014). Administración de Recursos Humanos. Gestión del Capital Humano. México: McGraw Hill. 